\title{
PEPPERDINE
}

UNIVERSITY — Pepperdine Dispute Resolution Law Journal

Volume 21 | Issue 2

Article 4

6-15-2021

\section{Private Juries Within the Arbitration Framework: A Third Path In Dispute Resolution}

Lionel M. Schooler

Luke Gilman

Follow this and additional works at: https://digitalcommons.pepperdine.edu/drlj

Part of the Dispute Resolution and Arbitration Commons

\section{Recommended Citation}

Lionel M. Schooler and Luke Gilman, Private Juries Within the Arbitration Framework: A Third Path In Dispute Resolution, 21 Pepp. Disp. Resol. L.J. 457 (2021)

Available at: https://digitalcommons.pepperdine.edu/drlj/vol21/iss2/4

This Article is brought to you for free and open access by the Caruso School of Law at Pepperdine Digital Commons. It has been accepted for inclusion in Pepperdine Dispute Resolution Law Journal by an authorized editor of Pepperdine Digital Commons. For more information, please contact bailey.berry@pepperdine.edu. 


\title{
PRIVATE JURIES WITHIN THE
}

\section{ARBITRATION FRAMEWORK:}

\section{A THIRD PATH IN DISPUTE RESOLUTION}

\author{
By: Lionel M. Schooler ${ }^{1}$ \& Luke Gilman ${ }^{2}$
}

I. AbStract

In the context of a global pandemic and a resulting backlog of jury trials in the United States court system, this article explores the potential for employing a private jury system within existing arbitration law to provide a third path for parties seeking an expedient resolution of disputes by juries when impediments exist to jury trial in court. After an introduction and background on the current state of the global SARS-CoV-2 pandemic and its effect on court backlogs, we outline the law applicable to private jury proceedings, including (a) whether an arbitral award predicated on a private jury determination is enforceable; and (b) the requirements and limitations of a private jury award. We then conclude with a brief analysis of the considerations that parties seeking to employ private jury proceedings might implement to ensure such proceedings lead to a full and fair hearing and an enforceable award.

\section{INTRODUCTION}

The global SARS-CoV-2 pandemic necessitated court closures across the country, triggering a significant

${ }^{1}$ Senior Partner, Jackson Walker LLP, Houston, Texas.

${ }^{2}$ Partner, Jackson Walker LLP, Houston, Texas. 
backlog of cases. ${ }^{3}$ This phenomenon potentially poses a significant obstacle to timely jury trials. Other commentators have astutely noted that arbitration offers a flexibility that permits parties to resolve disputes without the need for courts to fully reopen and clear their backlog.

But what of the litigants who don't wish to discard their right to a jury trial merely for the sake of expediency? In contrast with jury trial or arbitration as the only dispute resolution alternatives, this article offers a third, hybrid path for willing parties: private jury trials in arbitration. While use of such a process is exceedingly rare, there is at least some precedent for conducting jury trials within the legal framework of arbitration.

We first analyze the boundaries of arbitration law and find there is ample flexibility therein for parties to agree to conduct a private jury proceeding. We consider next the logistics of such a procedure. We then turn to questions of enforceability and suggest that the role of the arbitrator should be similar to that of a judge in a traditional jury trial, that is, assessing the findings and accordingly translating a private jury's findings as applicable into an enforceable arbitration award in the same way that a judge translates a jury's sustainable answers to a jury charge into an enforceable judgment. Finally, we analyze some of the requirements and limitations of jury awards.

The demand for private jury proceedings in the absence of a global pandemic or a significant backlog in the court system may be relatively small, but we nevertheless consider it worthwhile to provide a means of establishing enforceable awards through private jury service when the need arises. Arbitration theoretically offers parties the opportunity to craft such specialized and unique dispute resolution procedures; however, in practice, practitioners'

\footnotetext{
${ }^{3} \mathrm{Al}$ Tompkins, COVID-19 shutdowns are creating court backlogs across the U.S., POYNTER.ORG (May 6, 2020), https://www.poynter.org/reporting-editing/2020/covid-19-shutdowns-are-creating-court-backlogs-across-the-u-s/. 458
} 
arbitration clauses rarely vary in the type of alternative proceeding utilized. ${ }^{4}$ Finally, in advocating a radically different type of arbitration process from what is typical, we suggest that contractual counterparties might consider a wider variety of suitably crafted dispute resolution provisions.

\section{BACKGROUND}

In the Spring of 2020, during the midst of the Coronavirus epidemic, courthouses across the United States began shutting their doors to all but the most urgent matters. ${ }^{5}$ Many courts quickly adopted capabilities to facilitate remotely addressing certain qualifying matters, but determining the merits of a dispute without requiring jury trial waiver remained an intractable obstacle. ${ }^{6}$

Some courts have proven admirably inventive, temporarily decamping from the courtroom to resume jury trials in buildings such as high school gymnasia and convention center spaces to comply with recommended social distancing and other safety precautions to ensure a juror does not undertake an extraordinary risk simply by performing his or her civic duties as a juror. ${ }^{7}$ Other courts have experimented

\footnotetext{
${ }^{4}$ See Daniel T. Pascucci, Dissecting Common Basic Arbitration Clauses -- You Can Build a Better One, MINTZ (Mar. 6, 2018), https://www.mintz.com/insights-center/viewpoints/2196/2018-03-dissectingcommon-basic-arbitration-clauses-you-can-build.

${ }^{5}$ See e.g., Matt Hamilton \& James Queally, Coronavirus: All California trials delayed; L.A. County courts close to the public, LA TIMES (Mar. 23, 2020), https://www.latimes.com/california/story/2020-03-23/coronavirus-californiadelays-trials-la-county-shuts-courts-to-public.

${ }^{6}$ Maggie Jo Buchanan, The Pressing Need To Support Courts During the Coronavirus Crisis, AMERICAN PROGRESS (Apr. 7, 2020), https://www.americanprogress.org/issues/courts/news/2020/04/07/482712/pressing-need-supportcourts-coronavirus-crisis/.

${ }^{7}$ Blaine Corren, Jury Service Begins for Trials Delayed by COVID-19 Pandemic, CALifornia Courts Newsroom (June 26, 2020), https://newsroom.courts.ca.gov/news/jury-service-begins-trials-delayed-covid-19-pandemic.
} 
with remote summary jury trials, with promising results. ${ }^{8}$ However, thus far, courts do not appear able to undertake these extraordinary measures at a sufficient scale to permit such relocated jury trials as a matter of routine for all of the litigants who might otherwise avail themselves of that right. In the meantime, a considerable backlog of cases awaiting trial appears to be developing. ${ }^{9}$

A number of courts have offered remote bench trials with some apparent success. ${ }^{10}$ Most courts have offered bench trials as an option to litigants to expedite the time in which their trial can be heard. ${ }^{11}$ Yet this can hardly be hailed as a solution, given that it compels a litigant's forfeiting trial before a jury of his or her peers as the cost of escaping further delay. ${ }^{2}$

Of course, pre- or post-dispute arbitration is another alternative available to litigants willing to agree to it. Even so, as traditionally practiced, arbitration bears many of the

\footnotetext{
${ }^{8}$ Mark Paladino \& David Zaslow, Virtual Jury Trials: The Next Wave of Remote Legal Practice, JD SUPRA (June 5, 2020), https://www.jdsupra.com/legalnews/virtual-jury-trials-the-next-wave-of-29445/.

${ }^{9}$ E.g., Chris Crook, Courts Battling COVID-19 Backlog, ZANESVILle TimES RECORDER (July 11, 2020), https://www.zanesvilletimesrecorder.com/story/news/local/2020/07/11/courts-battling-case-backlog-due-covid-19-pandemic/3258903001/.

${ }^{10}$ See generally Jennifer Lapinski, Robert Hirschhorn \& Lisa Blue, Zoom Jury Trials: The Idea Vastly Exceeds the Technology, LAW.COM (Sept. 29, 2020), https://www.law.com/texaslawyer/2020/09/29/zoom-jury-trials-the-ideavastly-exceeds-the-technology/.

${ }^{11}$ See Lauren Ernde, Pandemic Forces Courts and Lawyers to Reimagine Proceedings, THE BAR ASSOCIATION OF SAN FRANCISCO (Dec. 15, 2020), https://www.sfbar.org/blog/pandemic-forces-courts-and-lawyers-to-reimagine-proceedings/.

${ }^{12}$ Jessica A. Roth, The Constitution Is On Pause in America's Courtrooms, THE ATLANTIC (Oct. 10, 2020), https://www.theatlantic.com/ideas/archive/2020/10/constitution-pause-americas-courtrooms/616633/.
} 
same limitations as a bench trial, coupled with some additional, perceived, limitations such as limited rights of appeal or review. ${ }^{13}$

Taking all of these factors into account, extraordinary conditions may impel the use of extraordinary procedures. For many litigants, waiting for a jury trial is not a realistic or tolerable solution. ${ }^{14}$ Justice delayed may very well be justice denied. While many judges have offered the option of bench trials as a quicker resolution method on a compressed schedule, this method sacrifices jury involvement for rapidity, and still carries with it the challenge to a litigant to weave in and out of the court's regular docket. ${ }^{15}$ Indeed, it has to be recognized that significant delays may attend even this compromise approach, given that the scheduling of any bench trial depends upon a judge's availability in a time of overtaxed resources.

The concept of a private jury trial, conducted by an arbitrator (or arbitration panel) in roughly the same manner as a court would, ${ }^{16}$ but under the auspices of an arbitration,

\footnotetext{
${ }^{13}$ For the pros and cons of ADR, see generally Matt Hoffman, The Advantages and Disadvantages of Arbitration vs. Court Litigation, TUCKER LAW (Feb. 13, 2015), https://www.tuckerlaw.com/2015/02/13/advantages-disadvantages-arbitration-vs-court-litigation/.

${ }^{14}$ Rick Ellsley, Can't Get a Civil Jury Trial Due to COVID-Related Court Closures? Try Arbitration, DAILY BUSINES REVIEW (Dec. 22, 2020), https://www.law.com/dailybusinessreview/2020/12/22/cant-get-a-civil-jurytrial-due-to-covid-related-court-closures-try-arbitration/.

${ }^{15}$ Jack Karp, Trial Alternatives Getting Fresh Look With COVID-19 Backlog, LAw360 (Feb. 4, 2020). https://www.law360.com/pulse/daily-litigation/articles/1351450/trial-alternatives-getting-fresh-look-with-covid-19-backlog.

${ }^{16}$ There is a tradition in arbitration practice for the parties to have either a sole arbitrator or a panel of three arbitrators; see AAA Comm. Rule R-16 ("[i]f the arbitration agreement does not specify the number of arbitrators, the dispute shall be heard and determined by one arbitrator, unless the AAA, in its discretion, directs that three arbitrators be appointed"); Dockser v. Schwartzberg, 433 F.3d 421, 428 (4th Cir. 2006) (holding that where American Arbitration Association determined that a proceeding should be heard by three arbitrators instead of one arbitrator according to its rules, that was a procedural question to be answered exclusively in that forum). Presumably a party seeking to employ a private jury proceeding might also be expected to adopt the traditional relationship of a single arbitrator as it would a single judge. However, nothing but
} 
may be relatively novel. ${ }^{17}$ As far as we can tell, no court has yet weighed in on the idea of a private jury in this particular context. In fact, one of the few references we located in published case law is a comment by the late Justice Scalia in the seminal arbitration case $A T \& T v$. Concepcion, who posited proceedings by "a panel of twelve lay arbitrators" as a fanciful retort, without opining on the enforceability of such a panel. ${ }^{18}$

However, we are aware of at least one instance where a private jury trial was tried in practice, conducted by retired federal judge Vaughn Walker and reported in a 2015 article by the Judge and counsel in the case. ${ }^{19}$ The authors of the article in which that proceeding is discussed appear to have considered use of that process a success. ${ }^{20}$

\section{What LaW Applies to Private Jury Pro- CEEDINGS?}

Arbitration is a creature of contract given special recognition by statute. ${ }^{21}$ Arbitrations in the United States

tradition and experience compel this approach. If a party adopts the view that having more than one arbitrator improves the quality of the process by increasing the deliberative capability of the panel, that party may seek agreement that three arbitrators hear the case in addition to a private jury. On the other hand, where a private jury undertakes the fact-finding role traditional to a jury, this would permit the arbitrator to focus on legal issues, reducing the overall burden of the arbitrator's role. A sole arbitrator is likely more expedient and cost-effective in this context, but a panel could be employed if desired by the parties. ${ }^{17}$ Robert A. Patterson, Reviving the Civil Jury Trial: Implementing Short, Summary, and Expedited Trial Programs, 2014 BYU L. REV. 4, 951, 965 (2015).

${ }^{18}$ AT\&T Mobility LLC v. Concepcion, 563 U.S. 333, 342 (2011).

${ }^{19}$ Hon. Vaughn R. Walker, David C. Wheeler \& Roy J. Jimenez, The Private Jury Trial of A Business Case, Litigation 5, 6 (2015); Roy J. Jimenez, How a Private Jury Trial Worked for My Client, 37-MAY L.A. LAw. 44 (May 2014). ${ }^{20}$ Walker, et. al, supra note 19.

${ }^{21}$ See Hamish Lal et.al, The Law of an Arbitration Agreement: Is it the of the seat or the law of the underlying contract?, LEXOLOGY (Jan. 30, 2020) https://www.lexology.com/library/detail.aspx?g=0b7ad713-9cc5-40a2-96da93a10f24543b. 
involving some measure of interstate commerce or when explicitly so indicated by the contracting parties are governed by the Federal Arbitration Act (FAA), ${ }^{22}$ with certain limited exceptions. ${ }^{23}$ Additionally, each state has its own state arbitration legislation which separately governs agreements to arbitrate subject to its own jurisdiction. ${ }^{24}$ To the extent that any state's arbitration law conflicts with either the express provisions of the FAA or its intent in promoting arbitration, the FAA preempts such a law. ${ }^{25}$

Courts applying the FAA have restricted their review of the procedural mechanisms that the parties agree to employ in an arbitral setting to the question of whether the dispute is within the scope of the agreement to arbitrate and whether the parties have agreed, expressly or implicitly, to adopt a particular set of rules by reference. ${ }^{26}$

Accordingly, from the perspective of the courts when reviewing arbitral awards, the procedures and evidentiary rules in arbitration are matters for the arbitrators to determine within the boundaries of the applicable arbitration

\footnotetext{
${ }^{22}$ Federal Arbitration Act, 9 U.S.C. $\S \S 1-16$.

239 U.S.C. § 1; see New Prime Inc. v. Oliveira, 139 S. Ct. 532, 537 (2019).

${ }^{24}$ Roth eT AL., 1 Alternative Dispute Resolution Practice Guide $§ 2: 11$ app. II-2 (listing state arbitration statutes).

${ }^{25}$ Kindred Nursing Ctrs. Ltd. P'ship v. Clark, 137 S. Ct. 1421, 1424-29 (2017).

${ }^{26}$ John Wiley \& Sons v. Livingston, 376 U.S. 543, 556-58 (1964) ("Once it is determined ... that the parties are obligated to submit the subject matter of a dispute to arbitration, 'procedural' questions which grow out of the dispute and bear on its final disposition should be left to the arbitrator."); Prudential Sec., Inc. v. Shoemaker, 981 S.W.2d 791, 794 (Tex. App. 1st 1998) (holding that there was no basis to find that an arbitration panel exceeded its authority by awarding punitive damages where the appellant did not put into evidence the arbitration agreement on which the scope of the panel's authority was based); 13D Charles A. Wright \& Arthur R. Miller, Federal Practice and PROCEDURE $§ 3569$ (3d ed. 2020) (quoting Sirotzky v. N.Y. Stock Exch., 347 F.3d 985, 990 (7th Cir. 2003), abrogated by Martin v. Franklin Cap. Corp., 546 U.S. 132 (2005)) ("Outside 'the most distant of outer bounds,' such as the use of undue means to procure an arbitration award, the Federal Arbitration Act does not regulate arbitration procedure").
} 
contract, rather than for a court to impose. ${ }^{27}$ Under this rubric, there is no per se prohibition on the use of a private jury in arbitral proceedings. Courts have generally held to the jurisprudential principle that whatever is not prohibited by law is permitted. ${ }^{28}$ In keeping with the general purposes of the FAA, as interpreted by the courts since its enactment, as long as a valid agreement to arbitrate has been found, there is very little to constrain the imagination of the parties in mutually selecting the procedure deemed best able to address their particular dispute, even if such a procedure is use of a private jury of their peers for fact-finding purposes.

\section{A. Are Arbitral Awards Predicated On Pri- VATE DETERMINATIONS ENFORCEABLE?}

Section 2 of the FAA broadly provides for the enforceability of any written provision in a contract "evidencing a transaction involving commerce to settle by arbitration a controversy thereafter arising out of such contract," ${ }^{29}$ and Section 9 provides for the confirmation of the resulting award and entry of a judgment on that basis. ${ }^{30}$ The FAA contains no other formal requirements addressing the nature of the proceeding itself in keeping with the concept of arbitration as a creature of contract. ${ }^{31}$ Thus, the enforceability of the determinations of a private jury proceeding turn on whether such a proceeding is an "arbitration" within the

\footnotetext{
${ }^{27}$ Mastrobuono v. Shearson Lehman Hutton, Inc., 514 U.S. 52, $57-58$ (1995); Vigortone AG Products, Inc. v. PM AG Prods., Inc., 316 F.3d 641, 647 (7th Cir. 2002); P \& P Indus., Inc. v. Sutter Corp., 179 F.3d 861, 867-68 (10th Cir. 1999); Sirotzky, 347 F.3d at 990.

${ }^{28}$ Kordel v. United States, 335 U.S. 345, 349 (1948).

${ }^{29} 9$ U.S.C.A. $\$ 2$.

30 U.S.C.A. $\$ 9$.

${ }^{31}$ Justice Brennan appears to have introduced the memorable phrase into the jurisprudence of arbitration in his concurrence in United Steelworkers of Am. v. Am. Mfg. Co., 363 U.S. 564, 570 (1960). The Supreme Court has also recognized that the contractual autonomy of the parties is not unlimited; see Hall St. Assocs., L.L.C. v. Mattel, Inc., 552 U.S. 576 (2008) (holding that simply because "arbitration is a creature of contract" the FAA does not permit parties to expand judicial review once the arbitration is completed).
}

464 
scope of the FAA, and whether the resulting determination by the arbitrator based upon the jury's determinations is an "award." "32

Courts have wrestled with whether or not appraisal proceedings constitute an arbitration within the scope of the FAA, concluding at various times that an insurance appraisal which only determines the scope of a loss is not an arbitration, ${ }^{33}$ and that a series of appraisals to determine a business valuation that would only fix the purchase price under certain circumstances and would not necessarily settle a dispute between the parties was not an arbitration. ${ }^{34}$ However, an appraisal of a company's valuation could constitute an arbitration where it fell within the scope of the definition of "arbitration" under the applicable state statutory definition. ${ }^{35}$ The essence of these existential determinations is not, however, the form that such a proceeding takes, but whether or not such a proceeding results in a final adjudication of the dispute. ${ }^{36}$ Courts have emphasized the relative autonomy parties enjoy in fashioning an adjudicative process - " "[p]arties need not establish quasi-judicial proceedings resolving their disputes to gain the protections of the FAA, but may choose from a broad range of procedures and tailor arbitra-

\footnotetext{
329 U.S.C.A. $\S 2$.

${ }^{33}$ Hartford Lloyd's Ins. Co. v. Teachworth, 898 F.2d 1058, 1062 (5th Cir. 1990).

${ }^{34}$ Salt Lake Trib. Publ'g Co. v. Mgmt. Planning, Inc., 390 F.3d 684, 689-90 (10th Cir. 2004).

${ }^{35}$ Wasyl, Inc. v. First Boston Corp., 813 F.2d 1579, 1582 (9th Cir. 1987) (concluding that appraisal of assets fell within scope of California's statutory definition of "arbitration" where that definition included "valuations, appraisals and similar proceedings").

${ }^{36}$ Salt Lake Trib. Publ'g Co., 390 F.3d at 689-90 ("Central to any conception of classic arbitration is that the disputants empowered a third party to render a decision settling their dispute"); Harrison v. Nissan Motor Corp., 111 F.3d 343, 350 (3d Cir. 1997) (holding that "the essence of arbitration" is that parties "agreed to arbitrate [their] disputes through to completion, i.e. to an award made by a third-party arbitrator").
} 
tion to suit their peculiar circumstances"- - but it must be adjudicative and countenance that third party's decision to settle the dispute. ${ }^{37}$

For that reason, courts have generally rejected attempts to enshrine the traditional and oft-cited advantages of arbitration as cheaper, faster, and better than litigation. ${ }^{38}$ Generally, courts have not recognized these advantages as anything more than aspirational goals. ${ }^{39}$

In fact, a number of courts have upheld the arbitration of disputes that would otherwise be beyond the court's power to decide. ${ }^{40}$ For example, while the First Amendment's Free Exercise Clause constrains the judiciary from applying faith-based doctrine in cases before it, a court can compel religious tribunals to arbitrate many claims if the

\footnotetext{
${ }^{37}$ Salt Lake Trib. Publ'g Co., 390 F.3d at 690.

${ }^{38}$ Recent empirical studies tend to support the view that the arbitration process is generally substantially faster than the formal litigation process; also, the fee structure for certain types of cases such as plaintiff employment claims is often substantially cheaper to the initiating party as the costs in that kind of proceeding are borne by the employer under the rules of many arbitral institutions; see Andrea Cann Chandrasekher \& David Horton, Arbitration Nation: Data from Four Providers, 107 CAL. L. REV. 1 (2019), https://ssrn.com/abstract=3238460; Andrea Cann Chandrasekher \& David Horton, Arbitration Nation: Data from Four Providers, 107 CAL. L. REV. 1, 60 (2019).

${ }^{39}$ DeRose v. Jason Robert's, Inc., 216 A.3d 699, 716 (Conn. App. Ct. 2019), cert. denied, 218 A.3d 593 (2019) (holding that if parties wish to have their disputes resolved through arbitration within a particular time frame, they are free to do so contractually, but there is no established public policy rendering a protracted arbitration proceeding invalid).

${ }^{40}$ Sperry Int'l. Trade, Inc. v. Gov't of Isr., 689 F.2d 301, 306 (2d Cir. 1982) ("[A] court may not vacate an award because the arbitrator has exceeded the power the court would have, or would have had if the parties had chosen to litigate, rather than to arbitrate the dispute. Those who have chosen arbitration as their forum should recognize that arbitration procedures and awards often differ from what may be expected in courts of law.").
} 
parties have privately contracted for arbitration. ${ }^{41}$ As a result, courts have long interpreted the FAA to permit awards by religious tribunals. ${ }^{42}$

On the whole, we think that a private jury, which in fact falls on the more quasi-judicial end of the spectrum of permissible procedural options, dwells well within the existing definition of "arbitration" subject to and enforceable under the FAA. A private jury would readily survive a challenge on the ground that it bore too little resemblance to traditional arbitration, though, as noted above, no court appears to have considered such a challenge.

\section{B. What ARe the Requirements and Limita- TIONS OF Private JuRy Awards?}

To be clear, the relative procedural autonomy that the FAA provides to arbitration proceedings does not connote the absence of limitations. ${ }^{43}$ Indeed, the FAA authorizes grounds to vacate an award on substantive or procedural grounds:

(a) In any of the following cases the United States court in and for the district wherein the award was made may make an order vacating the award upon the application of any party to the arbitration-

(1) where the award was procured by

\footnotetext{
${ }^{41} 1$ Thomas OehmKe, Commercial Arbitration $\S 18: 12$ (2020).

${ }^{42}$ See e.g., Zeiler v. Deitsch, 500 F.3d 157, 162, 169 (2d Cir. 2007) (affirming an award by a "Bet Din" tribunal governed by "Halachic" or Jewish law); Meisels v. Uhr, 593 N.E.2d 1359, 1364 (N.Y. 1992) ("Whether or not the panel was specifically granted peshara authority, the arbitration agreements were broad enough to encompass disputes concerning title to the properties owned by the partnership - in fact, the first arbitration agreement specifically identified those buildings as subjects of the arbitration"); Ghertner v. Solaimani, 563 S.E.2d 878, 880 (Ga. Ct. App. 2002) ("[T]he results of a Bet Din, conducted pursuant to the Georgia Arbitration Act, are enforceable pursuant to that Act. This conclusion is supported by decisions of courts of sister states which have considered the specific issue of a Bet Din.").

439 U.S.C. $\$ \S 1-16$.
} 
(2)

corruption, fraud, or undue means; where there was evident partiality or corruption in the arbitrators, or either of them;

(3) where the arbitrators were guilty of misconduct in refusing to postpone the hearing, upon sufficient cause shown, or in refusing to hear evidence pertinent and material to the controversy; or of any other misbehavior by which the rights of any party have been prejudiced; or

(4) where the arbitrators exceeded their powers, or so imperfectly executed them that a mutual, final, and definite award upon the subject matter submitted was not made. $^{44}$

As a result, a private jury trial conducted within the framework of an arbitration must meet the same standards as an arbitration before a panel to yield an enforceable award.

Similarly, a valid arbitration clause must, at minimum, employ procedures that allow each party to present its case. ${ }^{45}$ This statutory requirement would remain in force whether or not the parties chose to employ a private jury in their proceeding. ${ }^{46}$

\footnotetext{
44 U.S.C. $\S 10(a)$.

${ }^{45} 9$ U.S.C. $\$ 10$ (a)(3); Tempo Shain Corp. v. Bertek, Inc., 120 F.3d 16 (2d Cir. 1997) (vacating award where arbitrators refused to continue hearing to permit testimony by company's official and record did not support arbitrators' finding that a company official's testimony would have been cumulative).

469 U.S.C. § 10(a)(3).

468
} 
The Supreme Court has held that " $§ \S 10$ and 11 respectively provide the FAA's exclusive grounds for expedited vacatur and modification." 47

Thus, although some courts have justified greater deference to an arbitrator's decision on the basis that the parties bargained for a theoretically informal, speedy, and inexpensive process in arbitration, ${ }^{48}$ that oft-cited policy justification for arbitration is not in any way a substantive bar to the parties' exercising their autonomy by choosing any proceeding they may see fit to employ, so long as it meets the basic requirements of the FAA. ${ }^{49}$

It must be recognized that the FAA's wording triggers a textual issue: it contains no language expressly prohibiting private juries as fact finders, but neither does it provide for private juries. ${ }^{50}$ Indeed, the FAA clearly contemplates that the obligations of decision-making in an arbitration will be made by arbitrators. ${ }^{51}$

\footnotetext{
${ }^{47}$ Hall Street Assocs., L.L.C. v. Mattel, Inc., 552 U.S. 576, 582 (2008); see Davis v. Producers Agr. Ins. Co., 762 F.3d 1276, 1283 (11th Cir. 2014), cert. denied, 135 S. Ct. 1555 (2015) (stating that arbitrators' awards "will be vacated only in certain narrow circumstances defined in the statutes"); Parker v. ETB Mgmt., L.L.C., No. 15-11128, 2016 WL 4151216, at 1 (5th Cir. Aug. 4, 2016) ("[W] may only vacate an award when it violates one of four grounds specified in the Federal Arbitration Act.").

${ }^{48}$ Matter of Andros Compania Maritima, S.A. (Marc Rich \& Co., A.G.), 579 F.2d 691, 701 (2d Cir. 1978) (opining that "even greater caution is justified when the decision to be set aside is the product of the theoretically informal, speedy, and inexpensive process of arbitration, freely chosen by the parties"). ${ }^{49}$ In re A.H. Robins Co., Inc., 42 F.3d 870, 875 (4th Cir. 1994) (noting that "there is no common law of arbitration"); Volt Info. Scis., Inc. v. Bd. of Trustees of Leland Stanford Junior Univ., 489 U.S. 468, 469, 109 S. Ct. 1248, 1250, 103 L. Ed. 2d 488 (1989) ("[a]rbitration under the Act is a matter of consent, not coercion, and the parties are generally free to structure their arbitration agreements as they see fit").

509 U.S.C. $\S \S 10-11$.

${ }^{51}$ In this regard, we suggest that the arbitrator, or a panel, would possess the authority given to judges under FED. R. CIV. P. 50 to evaluate whether a particular factual matter merits jury consideration or, put another way, whether the panel would possess the authority to declare a "judgment as a matter of law." We address this concept further at the end of this section.
} 
One solution is to consider whether each of the individual members of a prospective private jury would act as an arbitrator under the FAA. Here, one might be tempted to resort to Justice Scalia's whimsical conception of "a panel of twelve lay arbitrators" in AT\&T Mobility LLC v. Concepcion. ${ }^{52}$ It is worth noting that federal courts have been willing to consider, and confirm, awards issued by panels comprised of groups larger than some juries. ${ }^{53}$ In addition, a number of courts have been willing to consider arbitral awards issued by individuals who were neither lawyers nor experienced arbitrators. ${ }^{54}$ In fact, there is a long history of non-lawyers presiding as arbitrators, particularly when the subject matter has required specific professional occupational expertise such as engineering or accountancy, in which such expertise is elevated in importance above legal training or prior experience. ${ }^{55}$ We note that the arbitration's dictionary definition is likely broad enough to even include "a panel of twelve lay arbitrators." 56 Black's Law Dictionary defines "arbitration" as a "dispute-resolution process in

\footnotetext{
${ }^{52}$ AT\&T Mobility LLC v. Concepcion, 563 U.S. 333, 342 (2011).

${ }^{53}$ See Soaring Wind Energy, L.L.C. v. Catic USA Inc., 946 F.3d 742, 756 (5th Cir. 2020) (affirming an award issued by nine arbitrators, noting that the plain language of the arbitration agreement would permit each of the ten members of the joint venture to name an arbitrator, up to eleven under a clause intended to ensure an odd number of arbitrators on the panel).

${ }^{54}$ It is now well established that, though most arbitrators are in fact lawyers, there is no legal requirement that an arbitrator be a licensed attorney to serve as an arbitrator. See Domke on Commercial Arbitration, § 25:6 (Feb. 2020) ("Legal training is helpful, but an arbitrator need not necessarily be a lawyer."); Kirby v. Grand Crowne Travel Network, LLC, 229 S.W.3d 253, 255 (Mo. Ct. App. 2007); Ames v. Garfinkel, 11 Misc. 3d 1051(A), 814 N.Y.S.2d 889 (Sup. Ct. 2006) ("[a]s arbitrators need not be judges or even lawyers, the failure of a party to present the rule of law explicitly to the arbitrators forecloses such party from claiming that the arbitrators have "manifestly disregarded" it."); Kintzele v. J.B. \& Sons, Inc., 658 So. 2d 130, 134 (Fla. Dist. Ct. App. 1995) (drawing distinction between legal and potentially intended use of term "punitive" on the basis that "arbitrators are generally businessmen chosen for their expertise in the particular subject matter of the suit ... who need not be lawyers").

${ }^{55}$ Kintzele v. J.B. \& Sons, Inc., 658 So. 2d 130, 134 (Fla. Dist. Ct. App. 1995).

${ }^{56}$ Arbitration, Bryan A Garner, BLACK's LAW DiCTIONARY (Thomson West, 10th ed, 2014).

470
} 
which the disputing parties choose one or more neutral third parties to make a final and binding decision resolving the dispute." 57 As described above, the courts which have considered the variety of permissible arbitration procedures have focused primarily on whether or not the mechanism chosen will result in a final adjudication within the guardrails of Section 10 (a) of the FAA. ${ }^{58}$

However, we think the better practice is for the role of an arbitrator and a private jury to operate in distinct spheres, mirroring the use of juries in court cases, for reasons we describe below. A party seeking trial before a jury is typically seeking a process involving his peers rather than the mere multiplying of the size of the panel with its attendant-increased costs. ${ }^{59}$ While no legal training is necessary for a juror to act as a peer and provide the benefit of his life experience, judgment and attention to assessing credibility of witnesses and making determinations of fact (the role of the arbitrator as the FAA contemplates it) does require some legal knowledge in order to render an enforceable

\footnotetext{
${ }^{57}$ Arbitration, Bryan A Garner, BLACK's LAW DiCTIONARY (Thomson West, 10th ed, 2014).

${ }^{58}$ Hall Street Assocs., L.L.C. v. Mattel, Inc., 552 U.S. 576, 582 (2008); see Davis v. Producers Agr. Ins. Co., 762 F.3d 1276, 1283 (11th Cir. 2014), cert. denied, 135 S. Ct. 1555 (2015); Parker v. ETB Mgmt., L.L.C., No. 15-11128, 2016 WL 4151216, at 1 (5th Cir. Aug. 4, 2016).

${ }^{59}$ Jurors in federal court are paid $\$ 50$ a day for both Petit Jury and Grand Jury service. 28 U.S.C. $§ 1871$ ("A juror shall be paid an attendance fee of $\$ 50$ per day for actual attendance at the place of trial or hearing" in addition to other discretionary fees based on length of service). However, this is below the $\$ 58.00$ per day a person would be paid for an eight-hour day at the federal minimum wage of $\$ 7.25$. The national mean hourly wage as of the 2018 was $\$ 24.98$. An eight-hour day at the national mean hourly wage would yield $\$ 199.84$ per day. While the prevailing market for prospective jurors may vary across locales, we suggest that $\$ 200$ per day may be a baseline expectation for a jury fee that could attract a cross-section of private jurors and be sufficient to encourage active participation; Lance T. Marshall, What Does it Mean to Have a Jury of Your Peers, LAW OfFICES OF LANCE T. MARShall (2019), https://www.statecollegecriminallawyer.com/blog/2019/05/what-does-itmean-to-have-a-jury-of-your-peers/.
} 
award. ${ }^{60}$ To require this of a panel of "peer" jurors likely invites potentially costly mistakes that may rise to the level of requiring vacatur of the award.

On the other hand, if an arbitrator dismisses, contradicts, or ignores a jury's findings, the whole point of employing a private jury in the first place may be called into question. The appropriate standard for resolving a distinction between jury determinations and arbitrator discretion properly to translate such determinations into a just and enforceable award may be found in Federal Rules of Civil Procedure Rule 50 (Fed. R. Civ. P. 50), the federal court's procedural tool establishing the standard for judgment as a matter of law in a jury trial. ${ }^{61}$ This failsafe process is appropriate to ensure that the private jury trial concept retains its essential function as a dispute resolution mechanism, rather than a dispute creation mechanism, by permitting a split of opinion or authority among the legal and/or fact finders without determining which opinion will prevail in the award. To this end, it is suggested that the arbitrator or panel is in the best position to ultimately determine, in accordance with the adopted procedures, whether and to what extent the jury's findings can be incorporated into an award.

\section{How Should Private Jury Proceedings WORK?}

Assuming the parties agree that their dispute should be resolved by a private jury along the lines, there remains the question of how such proceedings should work.

As aforementioned, the foundation for utilizing a private jury in an arbitration proceeding derives from the agreement of the parties. $^{62}$ Thus, the parties should

\footnotetext{
${ }^{60}$ U.S. Arbitration Act "FAA" 43 Stat. 883 (1925) codified at 9 U.S.C. Ch. 1.

${ }^{61}$ FED. R. CIV. P. 50.

${ }^{62}$ See Salt Lake Trib. Publ'g Co. v. Mgmt. Planning, Inc., 390 F.3d 684, 690 (10th Cir. 2004).
}

472 
anticipate various procedural issues and address these to the extent possible in their agreement. These issues could include:

(a) the size of the proposed jury;

(b) the method for selecting such a jury;

(c) the method for compensating the service provided by such a jury;

(d) the agreement for jurors to sign (covering such matters as confidentiality of the proceedings); and

(e) the process by which to instruct the jury as to applicable legal principles governing its deliberations.

To ensure efficacious use of private juries, the parties may also want to consider any streamlining techniques to ensure the best possible use of the jurors' time. ${ }^{63}$

Further, the parties need to consider the extent to which the jury's role as factfinder will stand inviolate or, as with Fed. R. Civ. P. 50, be subject to review by the arbitrator under certain well-established principles. ${ }^{64}$ If a Fed. R. Civ. P. 50 standard is adopted, and a proper challenge is timely lodged to the eligibility of an evidentiary matter to be submitted to the jury, then it is anticipated that the arbitrator would assess the impact of the jury's factual determinations upon a final award.

For example, in most arbitrations, arbitrators do not strictly enforce any rules of evidence in terms of permitting

\footnotetext{
${ }^{63}$ Consideration must be given to the manner in which private jurors are selected. With most arbitration service providers, arbitrators as neutrals are required to make timely disclosures about their existing or potential relationships with parties and witnesses. ETHICS STANDARDS FOR NEUTRAL ARBITRATORS IN CONTRACTUAL ARBITRATION No. 7. Therefore, the parties would need to ensure that the identity of selected jurors is made known to an arbitrator before starting a hearing to ensure the disclosure process is appropriately enabled.

${ }^{64}$ FED. R. CIV. P. 50.
} 
or not permitting a party to present evidence. ${ }^{65}$ A judge must hear and review evidence in order to determine its admissibility. ${ }^{66}$ It makes little practical sense for an arbitrator to review evidence in order to determine whether or not they themselves can then consider it as evidence on the merits of the case. This is not so with a jury. While on the one hand, it might seem expedient to the parties to employ rules of evidence in the same way that a court would, we think this is another example in which the parties might choose a third path and opt for a complete presentation of the entire case before the jury panel, giving it an opportunity to deliberate and reach a decision, but reserving to the arbitrator the right to entertain, if properly raised, challenges to the jury findings on the basis of Rule 50 standards. The arbitrator could either announce a ruling at the time of the objection or incorporate a ruling on any Rule 50 motions into the award.

With these procedures in hand, the parties can then confer with the arbitrator at the outset of the proceeding, as is now done with "preliminary management conferences" and the like, to decide other procedural questions, such as: (a) opening and closing statements; (b) examination of witnesses; (c) applicable evidentiary standards; and (d) use of exhibits, including demonstratives.

Once these procedures have been agreed to and memorialized in an appropriate Scheduling or Procedural Order along with other typical scheduling matters, such as discovery deadlines and the like, the parties should have at their disposal the appropriate road map to prepare the case for the hearing.

\footnotetext{
${ }^{65}$ Best Practices Regarding Evidence in Arbitrations, AMERICAN COLLEGE OF TRIAL LAWYERS, (Feb. 2018)https://www.actl.com/docs/defaultsource/alternative-dispute-resolution-

committee/adr_best_practices_regarding_evidence_in_arbitrations.pdf?sfvrsn $=2$.

${ }^{66} \mathrm{See}$ FED. R. EvID. 104(a).

474
} 


\section{CONCLUSION}

As demonstrated above, the use of a private jury within the context of an arbitration proceeding is a workable and enforceable procedural mechanism that provides a potentially useful option for parties voluntarily agreeing to employ it. For many litigants, the opportunity to have one's case heard by a jury of one's peers represents an essential feature of the American civil justice system. ${ }^{67}$ At the same time, arbitration often provides flexibility and expediency to litigants, particularly at times when the court system faces significant backlogs and delays in conducting jury trials. This analysis demonstrates that litigants can have their jury and arbitrate too, using the flexibility of arbitration to craft an evidentiary procedure that incorporates the use of a jury charged with performing its quintessential fact-finding role.

Such a proceeding is not for the faint of heart. The parties must first agree to utilize a private jury. Then, they must agree upon how to use such a jury and upon what procedures apply. Here, the court system provides a model and a reference point. Some might say this is merely litigation by another name. Indeed, it can be. Yet, it need not be so limited. The parties are free to craft the structure of their proceeding and may adopt the process outlined herein or go further. Private juries are simply one of many different tools in the toolbox of arbitration. However, as the SARS-CoV-2 pandemic threatens the availability of timely jury trials on an unprecedented scale, arbitration offers an alternative venue for both parties seeking to employ juries to resolve their disputes, and the juries to do so. ${ }^{68}$

\footnotetext{
${ }^{67}$ Mark Chalos, Why fair trials are important to the American legal system, TENNESSEAN (Jan. 18, $2020 \quad 6: 00 \quad$ AM) https://www.tennessean.com/story/opinion/2020/01/18/fair-trials-keyamerican-legal-system-impeachment-donald-trump/4433403002/.

${ }^{68}$ Courts Suspending Jury Trials as COVID-19 Cases Surge, UNITED STATES COURTS, (Nov. 20, 2020) https://www.uscourts.gov/news/2020/11/20/courtssuspending-jury-trials-covid-19-cases-surge.
} 
Pepperdine Dispute Resolution Law Journal, Vol. 21, Iss. 2 [2021], Art. 4 